\title{
FEVERS AND OTHER FUNDAMENTALS: DUTCH AND GERMAN MEDICAL EXPLANATIONS c. 1680 TO 1730
}

by

\author{
JOHANNA GEYER-KORDESCH*
}

"FEVER" IS one of the most ambiguous of terms in use in the half-century c. 1680 to 1730. It is ambiguous because it covers a range of phenomena within contexts that historians are inclined to treat separately rather than to appreciate as an interlocking set of events in a very complex period of change. Since the bacteriological advances of the nineteenth and twentieth centuries, an analysis of "fevers" usually carries with it a demand to pin-point the scientific recognition of "disease entities". ${ }^{1}$ In many ways, however, this is an inappropriate question to ask. It separates one element of medical knowledge from its structural whole. This point should be heavily emphasized for any investigation into early eighteenth-century medicine because of the nature of medical theory of that time. We are dealing here with university-educated doctors and their medical knowledge, and it is historically incorrect to stress so much a category of analysis which they would not have perceived. No matter how much material may be unearthed for the recognition and spread of epidemic and infectious diseases - and such material is certainly present from the beginning of the eighteenth century and becomes more prominent with the beginnings of statistical record-keeping, for example, in Berlin - pathology and within it fevers remain firmly integrated with physiological explanations. With minor variations, any major teaching text or opera omnia of a leading medical man treats an individual disease only in the succession of physiology and pathology. ${ }^{2}$ Only in separate tracts or in the dissertations of pupils did specialized investigations into various diseases occur. These are certainly significant

\footnotetext{
*Johanna Geyer-Kordesch, Ph.D., Institut für Theorie und Geschichte der Medizin, Waldeyerstrasse 27, 4400 Münster, West Germany.

I wish to thank Don Bates for his interest and challenging questions which added zest to writing this paper, and Malcolm Deas of St. Antony's College for his kindness in carefully reading the manuscript.
}

'For a good discussion of the problem of disease ontology and "disease entities" see Owsei Temkin, "The scientific approach to disease: specific entity and individual sickness', in The double face of Janus and other essays in the history of medicine, Baltimore, Md., and London, Johns Hopkins University Press, 1977. Above all, this essay shows how varied the definitions of illness can be, providing support for my own effort of looking not at the evolution of a concept, but at its historical implications in a limited period and a specific set of events.

${ }^{2}$ Georg Ernst Stahl's Theoria medica vera, Halle, 1708, is a prime example. It is a logical necessity to read it in sequence: first the physiology and then the pathology. Most of his followers also used this progression. It is equally hard to imagine reading the works of the leading medical teachers of the time in any other way than the physiology followed by the pathology. For example: Michael Ettmüller, Opera omnia, 3 vols., Frankfurt/Main, 1697; or Georg Wolfgang Wedel, Physiologia reformata, Jena, 1688, followed by the Pathologia medica dogmatica, Jena, 1692. 


\section{Johanna Geyer-Kordesch}

for a precise grasp of the nature of individual diseases, and they were collected and read for this reason. But as with the clinical observations, which we will consider below, they did not intend to do more than convey as precise a description of disease as possible. When the description turned from the proximate and observable to the origins or ultimate causes of disease, invariably the discussion once more turned to physiology. In the early eighteenth century this meant above all explanations based on various theories relating to the consistency of the blood and the mode of its circulation.

Contrary to the nineteenth century, then, when pathological anatomy and bacteriological research led to a separate emphasis on disease as an ontological category of medical investigation, in the early eighteenth century one is faced with a curious but important structural difference: diseases were discussed and described in the pathologia specialissima and the "clinical observations" but did not receive any theoretical explanation apart from the inner dynamics of the body. To look for the medical explanations of "fevers" in this period one has consistently to deal with ultimate and comprehensive views as varied as those contained in chemiatric, mechanistic, vitalist, and other explanations, as well as descriptions of individual patients and individual records of disease. In tracing de febribus, the labels of smallpox, tuberculosis, malaria, catarrhal fever, etc. all appear, but only as the practical end of the theoretical spectrum of medical explanation.

Disease as an entity governed by the laws of an unfolding reaction between microorganism and the body does not exist. Disease as a process unfolding within the definitions of how the body works and functions does. But again there was no consensus in the late seventeenth century on these matters. The battle between the "ancients", the accumulated knowledge from the heritage of Galen and Avicenna, renewed and diversified in the sixteenth century, and the "moderns", attempting to assimilate the circulation of the blood and other new physiological and anatomical knowledge, had intensified. As we look at some of the critical, vernacular writing in medicine among the Dutch and the school of Georg Ernst Stahl, professor of medicine at Halle in Brandenburg-Prussia, at every stage these issues become more apparent. The period from 1680 to 1730 was one of both revision and innovation.

But while all medical roads lead back to the assumption that disease and in particular the fevers have some comprehensive "internal" explanation, controversial and varied as these may now be, another area of medical concern complicates the picture further. Criticism and reform of medical ideas did not originate with an academic desire for change. Neither did seventeenth-century medical science progress in the linear form one might expect from a chronology of its major discoveries. Revision and reform had some of their deepest roots in the practical problems the physician faced in cure and medication. Contrary to our own assumption of the split between scientific investigation and the common general practitioner, those doctors with university degrees we will deal with here wrote their books of criticism and advice as common general practitioners. They contended with the double burden of the learned doctor and the expectation of considerable theoretical expertise as well as with the practical encounters with disease, encounters as heterogeneous as their patients. Furthermore, they had to evaluate their own and others' use of drugs and cures. In the 


\section{Fevers and other fundamentals: Dutch and German medical explanations}

background their formidable economic rivals, the empirics, were ever present to take their patients.

The concept of "fevers" from 1680 to 1730 , even if restricted to learned doctors and to a few representatives among the Dutch and the newly prominent school of Stahl, presents a formidable range of the problems within medicine: a dissatisfaction with some of the constructs of theory while not denying that disease has "internal" roots of origin; the practitioner's struggle with effective cures and remedies leading to a criticism not only of specific drugs, but also to the revision of theory as the rationale for therapy; and last but not least, the struggle to look at individual illnesses more closely, as in the casebooks, with its concomitant insights into what was gaining recognition as malpractice and "false" medication. This latter captured the critical attention of these physicians, but it is not separate from the rest. Empiricism alone, as Stahl pointed out repeatedly, cannot suffice where an extensive knowledge of the body's dynamics in health and individual disease is required. Therapeutic practice necessitates knowledge of the genesis, symptoms, and prognostic patterns of disease. By 1680 , to judge from the Dutch and German vernacular literature, a state of controversy reigned.

The evidence for these assertions about the perception of disease, theory, and practice comes from a growing vernacular literature written by Dutch and German physicians from $c$. 1680. In now looking specifically at fevers this will be our material. The main Dutch representative was Cornelis Bontekoe, but he also had close associates in Heydentryck Overkamp and Stephan Blankaart. These physicians were not members of a university faculty of medicine but town practitioners, mainly in Amsterdam. Their motivation for writing medical books was to challenge their fellow practitioners, including the faculty at Leyden. The second group of doctors who thought it expedient to carry medical matters before a lay public were the followers of Georg Ernst Stahl. Their motivation was twofold: to popularize the ideas and methods of Stahl which they claimed revolutionized healing practices, and to counteract the orientation of medicine towards laboratory experiment and anatomy which they saw as deterimental to the work of the practitioner.

The Dutch physicians merit being called a "group" - albeit very small - because they consistently referred to each others' writing and work in their publications. They have been almost completely but unjustly ignored by medical historians. ${ }^{3}$ Blankaart's medical dictionary, for example, was republished even into the first quarter of the nineteenth century. Their main contribution to the changing medical situation at the end of the seventeenth century, however, is a set of vernacular medical publications. These books represent an early major incursion into the market of lengthy medical explanations written for the educated public rather than for the university audience of

\footnotetext{
${ }^{3}$ In tracing information on these physicians, who are prominent enough in library catalogues and the book fair lists of Frankfurt/Main and Leipzig relating to the period, one is faced with the law of inverse proportions. There is one reference to Bontekoe under Leeuwenhoek in the Dictionary of scientific biography (New York, Charles Scribner's Sons, 1973, vol. 8, p. 127); paragraph description in A. Hirsch, Biographisches Lexikon der hervorragenden Aerzte aller Zeiten und Völcker, 3rd ed., Munich and Berlin, 1962; and full entries in Zedler's Universallexikon aller Wissenschafien und Künste, ..., Leipzig and Halle, 1744.
} 


\section{Johanna Geyer-Kordesch}

medical doctors, where learned contributions were usually in Latin. This turning to the vernacular was certainly polemical. It meant that medical information - in the view of these physicians - should be discussed and judged by anyone capable of following the argument, and it put knowledge in the hands of patients as well as doctors. This radical strategy had its correlation in the content: these town physicians wanted to break with a number of still current traditional medical theories.

With regard to the fevers, this attitude is well exemplified by Cornelis Bontekoe's Traité des fièvres où l'auteur découvre l'erreur des Médicins anciens et modernes, tant en leur theorie que dans leur pratique (Utrecht, 1682), first published in the Dutch vernacular in 1681. It was written with punch and wit to fulfil in a popular rather than erudite style the promises of its title. The Traite des fièvres illustrates well the dissatisfactions he felt about both received medical tradition and current explanations. It is not itself a scientific exposition so much as a sweeping, sometimes superficial, discussion of other people's fever explanations, calculated to make them seem slightly ridiculous, scientifically shortsighted, and far from rational. He attacked, however, many illustrious names which held sway over contemporary medicine: Sylvius, Willis, Barbette, and the followers of Paracelsian chemiatric medicine. His tract has all the marks of later enlightenment polemics against witchcraft and superstition, as for example the Monatsgespräche $e^{4}$ of Christian Thomasius. These "monthly dialogues" were published in the 1690s in Germany and were notorious first for their use of the vernacular, and second for their satirical treatment of much professional erudition as pedantry. The German translation of one of Bontekoe's medical works earned Thomasius's full approval. ${ }^{5}$ Like Thomasius, Bontekoe cultivated sharp wit rather than scholastic proof to do his opponents down. Like Thomasius's victims, his own were found among the fashionable and representative learned circles. Bontekoe condemned current fever explanations in attacking the following prevalent ideas: (1) that fever was a preternatural heat, whose source of incandescence was the heart and which is distributed by the blood; (2) that fever was created when the blood overheated itself (referring to the theory of motion and friction during the circulation of the blood); (3) that fever stemmed from an increase in the pulse rate; (4) that fever was created through fermentation in the blood (pp. 6-7).

These explanations of fever were based on various theoretical systems. We follow here Bontekoe's attacks on each and then explore his subsequent arguments in the Traite for abandoning the curing methods and use of remedies derived from these explanations. First, he discredited the ideas of the "ancients" and then moved on to the theories of his contemporaries, the "moderns".

The classic notion of fever as preternatural heat stood for all variations of fever theory which had been current in the seventeenth century and derived from the medicine of the "ancients". This theory supposed the heart to be the source of a heat opposed to the natural heat of the body which was then diffused through the arteries

\footnotetext{
'Christian Thomasius, Freimütige, lustige und ernsthafie, jedoch vernunfimässige Gedanken oder, Monatsgespräche über allerhand, fürnehmlich aber neue Bücher, Halle, January 1688-April 1690 (Frankfurt/Main, Athenäum Reprints, 1972).

'Ibid., December 1689, pp. 1042 ff.
} 


\section{Fevers and other fundamentals: Dutch and German medical explanations}

and veins. It was basically an "internal" theory which could then be extended into a scheme of symptomatic descriptions, such as those of hotness and dryness. The fever caused an imbalance, whose manifestations were hotness and dryness. Bontekoe did not wish to do justice to the fine complexities of these systematic explanations. His intention, like Samson pulling down the pillars, was to destroy the whole edifice. Even the peasants know, he wrote, that a great heat makes the body more dry and hot. Imbalance is an invented term, signifying nothing (p. 13). To distinguish between preternatural heat and natural heat is like saying that the difference between fire and fire is akin to the difference between fire and water or light and darkness (p. 12). The argument by disdainful analogy was of course no proof at all, but proof was not necessary for arguing in the metaphor of light and darkness.

These were the formidable metaphors of the Enlightenment, and Bontekoe wished to invoke precisely that connotation of the difference between light and darkness when he banished preternatural heat and the notion of the heart as the hearth-fire of the body. The heart is a pump, Bontekoe wrote laconically. ${ }^{6}$ The Traite des fievres was only the beginning of Bontekoe's grand onslaught against the "ancients". It had been the last "oration" he gave in his embattled position in The Hague before he moved to Amsterdam for what he hoped was a more liberal climate among physicians. ${ }^{7}$ His biographer, the medical doctor Overkamp, related that his opponents in The Hague "puffed up with evil" at Bontekoe's success, sought refuge with Galen, Avicenna, and Aristotle but that there they "knocked upon the doors of the deaf and found only more words instead of substantial things" ${ }^{8}$ In a laudatory letter of Bontekoe's used as an introduction to one of Overkamp's own vernacular medical books, very quickly also translated into German, the need for new foundations in medicine was made even clearer:

$\ldots$ and even if the people since the time in which the great Hippocrates lived sank into a deep lethargy in order to do nothing but lie in bed and were as if sick with fever willing only to rest because they relied on the ancients and revered no one else but them so now the most fortunate of times has dawned in which the fogs will clear and the bright sun of diligent inquiry will rise in hearts and minds.'

He then named the new philosophy (of Descartes), the "bright light of anatomy", the "shimmering flame of chemistry", and experiments as the harbingers of truth. ${ }^{10}$

The Traite des fievvres took its place on the battlefront with other popular works. Overkamp wrote that the first part of the "New edifice of surgery" (Neues Gebäude der Chirurgie) was a well-placed "hand-grenade" 11 and the "Oration on the fevers" which followed, was produced after five years "on the battlefield" of The Hague. ${ }^{12}$ The

\footnotetext{
'Cornelis Bontekoe, Kurtze Abhandlung von dem Menschlichen Leben/Gesundheit/Kranckheit und Tod ...., Budissin, 1688, p. 25.

'Cornelis Bontekoe, Newes Gebäw der Chirurgie ... nebst des Herrn Autoris Lebenslauf (trans. into German by J. P. Albrecht, Med.D.), Hannover, 1687, p. 934.

I Ibid., p. 933

'H. Overkamp, Neues Gebäude der Chirurgie . . ., Leipzig, 1689; see letter reprinted in preface. All translations into English, in this case and the following, are my own.

10 Ibid.

11 Bontekoe, op. cit., note 7 above, p. 933.

12 Ibid., p. 934.
} 


\section{Johanna Geyer-Kordesch}

fevers, therefore, were prominent among the critical problems that Bontekoe singled out for his Cartesian return to first principles in medicine.

In addition to the "ancients", the "moderns" also came under "the bright sun of diligent inquiry in which the fogs will clear". Franciscus de Le Boë Sylvius, Bontekoe's own teacher, whom he said he could not spare criticism, as well as Thomas Willis, Paulus Barbette, another pupil of Sylvius and practitioner in Amsterdam, Regnier de Graaf, and the chemiatric school in the wake of Paracelsus, were all subjected to scrutiny. The ancients were dismissed with the scorn of the "modern" scientists, but the moderns fared no better. The fever explanations of the "moderns" had one crucial element in common: fever was a phenomenon characterized mainly by heat, although other symptoms were usually enumerated as attendant on it, and it was seen as originating from internal changes. The internal changes were no longer associated with "imbalance", but rather with the functions of the circulation and the blood. Thomas Willis, for example, explained fever as the product of fermentation in that set of events when the chyme (or chylus, the material of the digestive processes carried with the blood) degenerated and corrupted the blood. In that case, Bontekoe wrote, dietary regimen would bring the cure for every fever, which everyone knew it did not (p. 51). But Bontekoe also found other logical faults: fermentation did not take place in substances in motion and yet the blood never ceased to circulate. And I ask you, wrote Bontek oe, have you ever seen a greater difference than that between blood and wine, or the fermentation of wine and the alterations which take place in the blood? (P. 46).

With Paulus Barbette, Bontek oe considered the merits of another prevalent internal explanation. He summarily dismissed Willis's fermentative theory as inapplicable to the physiological behaviour of the blood in the body, but Barbette's theory was more minutely refuted because it was closer to his own view. Barbette's explanation of febrile heat rested on the mechanical ideas of motion and friction involving the pulse and the circulation. Significantly, Bontekoe disagreed with Barbette by correcting rather than dismissing his explanation of the role of the pulse and the heart. Barbette had maintained that an increased speed in the circulation of the blood produced the heat of fever. The increased speed resulted from changes in the composition of the blood. The violent and quick pulse, a symptom attendant on fever, reflected these pathological changes. Bontekoe argued that such an interpretation was mistaken. The pulse, he maintained, was not related to the speed of the circulation of the blood. The illness itself resided in the changes in the blood; and some pathological changes produced a "slow and thick" blood which circulated much more slowly. As a consequence the heart must beat faster in order to keep the circulation moving (pp. 18-19). The pulse rate depended on the heart as a pump reacting to the consistency of the blood. Heat was not produced by the friction of an increased circulation, as fountains or rivers which move quickly do not result in water becoming hot (pp. 14-15). The argument against Barbette shows one of the strengths of Bontek oe's position: the ability to criticize explanatory fallacies in the "modern" conception of fevers derived from "internal" models whose roots lay in the observed characteristics of chemical or mechanical properties. Bontekoe's own counter-propositions, however, did not go beyond the assumption that an even more exact knowledge of anatomy or chemistry, 


\section{Fevers and other fundamentals: Dutch and German medical explanations}

for example, would correct the "speculative" systems of his contemporaries. Their detrimental influence in medicine was their reversion to a monocausal explanation which did not fit the facts:

Premièrement il faut sçavoir qu'ils sont extrémement blâmables en ce que toute leur pratique et leur spéculation, qui ne sont que des fausses imaginations, sont fondées sur une chaleur, un feu, une fermentation, une ébullition, une concoction, une bile, un phlegme, et une infinité d'autre choses (p. 65).

It is astonishing, therefore, to find Bontekoe in his own writing on the nature of disease declaring illness to have one general source. All disease originated from "retardation of the circulation of the blood and fluids". ${ }^{13}$ He then enumerated the "types" of disease (Arten der Kranckheit) which could result from the derangement of the fluid parts and the effect of their derangement on the physical fabric of the body. For example, an excess of acidity in the blood and fluids would harm the vessels because they were made of a wet substance like milk or egg white. ${ }^{14} \mathrm{~A}$ particular set of symptoms resulted from this particular derangement. Bontekoe did not give names to these "types"; he did, however, carefully link the particular lesions of "the retardation of the circulation of the blood and the fluids" with specific clusters of symptoms arising from them. By this method he tried to carry out the revisions he advocated, and incorporate his own empirical observations into a comprehensive system. When he wrote on the fevers, he therefore began by devoting a sub-heading to a summary of all possible fever symptoms. ${ }^{15}$ It was part and parcel of the criticism of the Traite that his contemporaries had fixed on the symptom of heat rather than take into account the more various "signs" of a fever ailment. Bontekoe's list of symptoms encompassed twenty-one items which - he then cautioned - did not all appear at the same time or in any one particular disease. ${ }^{16}$ Contrary to expectation, however, this did not lead to a differentiation of fevers into separate entities. Bontekoe's next step was to revert once more to the physiological model of "thickness", "slowness", or "sharpness" in the blood and the fluids as the primary causes of fever and to the problem of the origin of these disturbances in the secretion of the organs and other "internal" factors. He only allowed the differentiation of fever types into intermittent and continuous as a practical guideline. In the Traite he had dismissed in no uncertain terms the classic division into ephemeral, putrid, hectic, and malignant fevers. ${ }^{17}$ This had been based on the theory that all fevers lay siege to the spirits, blood, or solid parts as a whole. ${ }^{18}$ For him, fever was an all-pervading physiological derangement.

From the Traite a number of fundamental lessons about the fever theory of the period ought to become clear. It was the product of a physician trained in what are historically seen as the "advanced" centres of medical learning in the Dutch republic. Bontekoe adopted an extremely critical position, waging a double battle against the continuation of the theory of the "ancients" which was still strong enough to cause him to leave The Hague, and against his contemporaries who were for the most part

\footnotetext{
${ }^{13}$ Bontekoe, op. cit., note 6 above, p. 152.

14 Ibid., p. 161.

15 Ibid., pp. 224ff. 'Von den Zufällen des Fiebers'.

16 Ibid., p. 226.

17 Bontekoe, Traité, p. 29.

18 Ibid., p. 30.
} 


\section{Johanna Geyer-Kordesch}

still concerned to explain fever in terms of heat, differing from the "ancients" primarily in using more "modern" physiological models. Bontekoe criticized the "moderns" on the grounds of specific anatomical (function of the heart and circulation) and chemical (no fermentation in the blood) fallacies. He also deplored their lack of practical observation in not taking enough notice of the diversity of symptoms attendant on fever. He was an enlightened reformer of medicine, an advocate of change, and perceived as such, but he did not attack the "internal" and encompassing (in physiological terms) explanation of the fevers as a fundamentally mistaken approach to disease. Even though he advocated an experimental and observational epistemology of disease, he did not depart from a physiological genesis. In short, he did not come to terms at all with a separate ontology of disease, nor did he advocate the distinct type of classification of fever illnesses which would lead to their nosography as "separate entities".

Illness is not "separate". The body's state of health turns into a state in which it is diseased. The possible causes for this change can be multiple and they are eagerly sought after in the network of examinable internal factors. The Latin phrase de morborum aetate, "of the period or time of sickness", is closer to the perception of illness in the late seventeenth century than "malaria", "typhus", or "smallpox". "Malaria", "typhus", "smallpox" for us label a pattern of disease imposed upon the body by various agents of infection. The same names were used in the late seventeenth century, but they represented a pattern of symptoms produced by the body. Disease produced within the body, the direct malfunction of digestion, circulation, or "balance" (as in the acidic corruption of the solid parts by the fluids), leads to very different assumptions about pathology. This is why Bontekoe or those he criticized did not develop a classification of "disease entities". While different symptoms indicate different fevers, their origins can be traced back to a more simple and uniform set of internal disturbances. The theory of these internal disturbances, not the symptoms themselves, dictate the measures to be taken in curing the disease. This was the next step that the Traite then logically pursued: the interconnexion between explanation and therapeutics.

But before examining this, it is worth reflecting on the very difficult problem of epidemiology. If specific fevers are in the course of medical explanation referred to origins in "internal" malfunctions, then an epidemiological description will record a collection of cases of the same disease, but not the typology of an infectious disease. The epidemiologies are of a geographical nature. They do not really expound the theory of contagion, other than perhaps the old miasmic theory of "bad" air or climate. Of course, in the texts discussed here, doctors were primarily writing about fever cases already in existence, not about preventive measures. Nonetheless, when reading about Willis's theory of fermentation as the explanation of fever and, in practically the same paragraph, of Willis's description of influenza and typhoid as being "first" before Sydenham and Morton in the "English tradition of epidemiology", one wonders whether these two things were completely unrelated. ${ }^{19}$ If the "state of illness" is perceived in terms of an "internal" origin and is healed accord-

19 R. G. Frank, jr., 'Thomas Willis', in Dictionary of scientific biography, op. cit., note 3 above, p. 405. 


\section{Fevers and other fundamentals: Dutch and German medical explanations}

ing to remedies driving out imbalances and circulatory disruptions, then epidemiology in this period was little more than the descriptive geography of disease. However, this question must be left aside here, since we are discussing primarily the explanations for fever and their cures. Contagion was not mentioned in these explanations, nor in the observational case descriptions dealt with below.

In the satirical comment on the remedies and practices derived from explaining fever in terms of harmful substances and the imbalance of humours, Bontekoe pointed an accusing finger at the link between "false" theory and "false" medication:

nos Docteurs d'aujourd'hui... ils purgent non seulement les mauvais humeurs, mais aussi les bonnes ... et comme ces humeurs sont un peu jaunes ou un peu brunes, nos Docteurs qui les considèrent de près avec deux yeux et une lunette, s'écrient d'abord qu'ils voyent de la bile, des phlegmes, et une matière aduste, quoiqu'il ne se trouve rien de tout çelà dans le basin, mais seulement dans leur cerveau renversé (p. 84-85).

It was this crucial link which Bontekoe acknowledged in the Traite when in the latter half he turned to a scathing review of fever remedies. In it he said that the theories which analysed fever mainly in terms of heat, sought the cure of the fever in "cooling drinks" (p. 67). Those who believed that the processes of fermentation caused heat while producing substances harmful to the body tended to rely on the tried and true methods of purgation and expulsion. Bontekoe attempted to destroy the logic which bound the remedies to the explanation. Since he tried to show that fever in terms of symptoms involved more than the predominant phenomenon of heat, he opposed remedies of a "cooling" nature. To try to "cool" the patient was like turning the sick out of their warm bed (p. 67). Hot things and remedies which possessed the virtue of warming were without danger in febrile illnesses; juleps and cooling potions, on the other hand, because of their "acidic" qualities slowed the blood even more (p. 74). "Slowness" and "thickness" of the blood, Bontek oe believed, were changes attendant on fever, and therefore to encourage such physiological changes would be harmful. He was even more opposed to the practices of bleeding and purging. Doctors bled, he wrote, in order to diminish, slow down, and cool the blood, and to relieve heat, boiling, and fermentation. This was like shadow-boxing, he said, because they tried to deal with something which did not exist (p. 76-77). Bleeding was a weapon of a pernicious and deadly nature (p. 77). If patients were bled during fever what usually followed was phthisis, yellow jaundice, and the dropsy connected with jaundice (p. 78). Frequent purgations were also founded on an imagination run wild, on the assumption that the body of those visited by fever was filled with rubbish and filth (rempli d'ordures et de saleté) and that this made it necessary to clean and wash with the force of apozems (watery preparations). If purgations cured fevers, one would not observe fevers persisting despite purgations, clysters, and apozems which were supposed to "wash" the fevers. It was like throwing out all the furniture to clean the house (p. 84). Even mild purgations were harmful because they removed a certain viscous humour which was needed in the stomach and intestine (p. 85).

Bontekoe's answer for medicative treatment in fevers was la chymie. A small grain of the right chemical substance is better than twenty or thirty pots of conserves, gallons of juleps, etc. It cured in a mild manner and without relapse (p. 88). His 


\section{Johanna Geyer-Kordesch}

opponents, he wrote, said this enclosed the fever. (One recalls that the remedies he criticized were all based on getting substances out of the body.) But, he answered, his method of chemical remedies was more like enclosing the wolf with the sheep. Even if the fever should return, however, the complications were less fatal than those caused by "false" medication (p. 89). Nowhere in the Traite, however, did Bontekoe give the exact composition of his own remedy. From other sources it is clear that he mixed his own, but he probably reserved this knowledge for use in his own practice.

Not the disease proper, but the physiological explanation determined the methods of curing. That is why the theoretical structure has such immense significance for practice. The common catchword bonus theoreticus, malus practicus, which prompted Stahl to write short reflections on the subject in $1697,{ }^{20}$ illustrates the contemporary awareness that remedies and curing methods were interwoven with the causal explanations rather than just the symptomatic discernment of disease. The problem thus perceived was not simply academic, or one related to the advancement of medical science in isolated university departments. All of the doctors discussed here also had large practices. Nor did their students practise the gentleman's art of private research; they all went into practice too. In addition, the learned doctors faced fierce competition. Throughout the vernacular books on medicine, one notes, first of all, that the ability to discern the complex interrelationship of first causes and symptoms (i.e. the "internal" theory) legitimized the calling of the learned doctor to the patient's bedside and, second, that this knowledge separated him from the empiric. The empiric, and competition from other quarters too, was present everywhere, and the most noticeable proof of competence was, of course, the efficacy of the cure. When Bontekoe fought against the use of bleeding, purgation, and evacuation in fevers, he wrote that after the patient had been reduced by the learned doctor to a miserable state, either death would claim him, or, if he should chance to be rehabilitated, the credit would go to some empiric, or to the good council of friends, or to some domestic remedy (p. 78). In other words, the avoidance of "false" medication based on "false" theories was also very intimately connected with the economic and professional status of doctors in this period, who faced a much broader competition than doctors of the nineteenth or twentieth centuries.

In these circumstances, the theory of fevers and the practical use derived from its explanations, methods of cure, and medication, tended to preoccupy those who defended their investment in learning. The author of the Patriotische Medicus, a periodical journal and one of the first German-language publications written by doctors for laymen, addressed this issue out of the same concerns. Of his fellow doctors, he wrote:

We are certainly not gods and we may never credit ourselves with an infallible and unbounded assurance
in our profession; but we do have a firm footing in that which we have tried and seen with our own eyes
because this is a better foundation for medicine than the deeply speculative; often-times experience takes
one further than pure reason, but it needs time as well as patience and perseverance so that one does not
skip from one remedy to the next if the effects of the medicine do not immediately become
apparent: .... I do not approve much of those doctors who suppose they are not living up to their office
if they do not prescribe a new remedy at each visitation: certainly the unforeseen success of some of these

${ }^{20} \mathrm{G}$. E. Stahl, Quis bonus theoreticus, malus practicus, Halle, 1697. 


\section{Fevers and other fundamentals: Dutch and German medical explanations}

will lead them into confusion so that finally they will blindly try this, that, and the other thing. Added to a judicious medical experience should be an untiring diligence in the examination of bodies and their illnesses as well as in examining the remedies against sickness and an unflagging awareness to acknowledge what one medicine does or does not accomplish and under which conditions and in which order it brings about its effects. (7 October, 1726, No. 56).

This passage contains the same aversion to "speculation" that Bontek oe had shown for his opponents' explanations of fever. It advocates the same spirit of careful observational techniques in describing and treating disease. Finally, at its core, one perceives the critical issue of cure and remedy. Empiricism as a guide is dismissed, for the learned doctor as well as for other practitioners, because of its tendency towards trial-and-error, of which the patient is the victim. The damage that "false" medication can do is more than acknowledged. What remains is an appeal for a better frame of reference by which those remedies whose observational value has been proven can be correctly applied.

This appeal for a theory allied with efficacy of curing was at the root of the German reform at the turn of the century among those doctors who looked to Georg Ernst Stahl as their guiding light. As with the medically heretical Dutch friends of Bontek oe, their thinking about fever involved the issues we have enumerated: the critical awareness of the inadequacy of "ancients" and "moderns"; the need for a better theoretical rationale for therapeutics; the acute consciousness of the danger of "false" medication.

Besides the similarities, however, there were some fundamental differences. For the moment we will leave the most basic difference aside, that of the whole complex of Stahl's definition of the body as a "psychosomatic" living entity which opposed those conceptions of the body in anatomical and mechanistic terms so favoured by the Dutch. Instead, we will focus on a more pragmatic detail: the intense interest shown by Stahl and his followers in recording cases in the most detailed and descriptive manner possible. In contrast to the Dutch, who were more content to explore the physiological functions of the body and to express the malfunctions of the pathological state in these terms, the school of Stahl produced a large number of publications devoted almost solely to disease descriptions as such.

Johann Storch published his Medizinische Jahrgänge, oder Observationes clinicae, darinnen er zeiget, wie die ihm anvertrauten Patienten nach den natürlichen oder Stahlianischen methodo curiret worden (Medical Yearbooks, or bedside observations, in which it is shown how the patients for whom he was responsible were cured according to the natural or Stahlian method) from 1724 to 1735 (Leipzig). These were, according to his own testimony, taken from the diary he kept of his own patients. He also published the fulsome Collegium casuale or Praxis Stahliana ${ }^{21}$ in three editions, which was primarily intended to serve the practitioner as a tool in recognizing and treating disease. Both of these works, which were not the only books

\footnotetext{
${ }^{21}$ Johann Storch, Praxis Stahliana, Das ist des Herrn Georg Ernst Stahls .. Collegium Practicum. welches teils von Ihm privatim in die Feder dictiert, theils von seinem damahligen Auditoribus aus dem Discours mit besonderem Fleiss nachgeschrieben ... vermehrt und verbessert, Leipzig, 1732. Storch had printed an earlier edition in 1728 which sold out within a year. This is the edition from which I quote. A third edition was published in 1745 .
} 


\section{Johanna Geyer-Kordesch}

Storch wrote on practical medical subjects, contained detailed case histories. The Breslauer Sammlungen ${ }^{22}$ as they are commonly known, was produced by several authors, among the most active being three students of Stahl. This periodical, published from 1717 to 1727 in Breslau, was a focal point for discussions on case histories and information on epidemic diseases. Stahl's own interest in the clinical case and the extensive use of it he made while teaching in Halle - the many texts that his pupils published were taken from their lecture notes, and a good many of these used his case histories - had never been documented. ${ }^{23} \mathrm{He}$ himself did not publish his Collegium practicum, his Collegium casuale, ${ }^{24}$ or his Observationes clinico-practicae ${ }^{25}$ because he stood firm in his belief that his theories as expounded in the Theoria medica vera (Halle, 1708) had to be digested by the medical world first. But all of the collegia and the observationes, whose source were manuscript copies or notes by students of Stahl's courses, were published - some in several editions - by the end of the 1730s. The books of the Dutch physicians, particularly those of Bontekoe, Overkamp, and Blankaart, did not show the same interest in case histories. The emphasis on the case history - in the popularization of medical knowledge we are addressing here - was a phenomenon encouraged and propagated by those dedicated to Stahl's teaching and method of practice.

We will select only one example among these numerous published works for its bearing on the theme of fevers. Fever cases were prominent in it, but by no means its sole preoccupation. However, it was a very significant publication in another sense, and therefore comparable to the Traite. It was a journal specifically designed for the same wider audience in medical topics as Bontekoe tried to attract with his popularly written discussion of fever theories. The Patriotische Medicus, quoted above, appeared from 6 November 1724 to 28 April 1727 on most Mondays in Hamburg. Although appearing anonymously, it was written by Johann Christoph Goetz, in unswerving follower of Stahl, who practised in Nuremberg.

The Patriotische Medicus adopted the style and didactic means of the popularized "moral weeklies". This genre of publications, a child of the eighteenth century enlightenment, sought to engage the general reader in discussions of non-academic import, ranging from political questions to matters of fashion, deportment, education of women, and moral habit. ${ }^{26}$ The 1720 s represent an early period in the development

22 Their true name is Sammlungen von Natur- und Medicin-Geschichten. They were referred to by their place of publication, Breslau. Storch, in the Praxis Stahliana (op. cit., note 21 above), makes frequent reference to the insights on observational cases they provide.

${ }^{23}$ I am currently working on a monograph on Georg Ernst Stahl in which I hope to treat extensively his influence on practical medicine in the eighteenth century.

24 The collegium casuale was printed through the offices of Storch, who also translated it into German: Collegium casuale magnum, oder 76. practische Casus, welche er [i.e. Stahl] von anno 1705 bis 1707 als Prof. Ord. auf der Universität Halle einem gewissen numero studiosorum nit gründlicher resolution und treuer Eröffnung vieler besonderer praktischer Cautelen lateinish in die Feder dictirt, Leipzig, 1733. The Collegium casuale, sic dictum minus ... in Latin was published in Schweidnitz in 1734. It was published in a second edition in Dresden and Leipzig in 1741.

${ }^{25}$ The observationes clinico-practicae were published in German for the first time in 1716 (Leipzig) and then in an improved translation in 1718. A fourth edition with index was published in 1735 .

${ }^{26}$ For an extensive discussion of the "moral weeklies" published in Germany, see Wolfgang Martens, Die Botschaft der Tugend. Die Aufklärung im Spiegel der deutschen Moralischen Wochenschrifien. Stuttgart, J. B. Metzlersche Verlagsbuchhandlung, 1968. He does not, however, discuss medical periodicals. 


\section{Fevers and other fundamentals: Dutch and German medical explanations}

of such popularized discussion, and the Patriotische Medicus shows the early participation of medical men in the attempt to provide access to medical knowledge. It covered, not surprisingly, a whole range of medical subjects in the cajoling but tried and true mixture of informative pieces interspersed with invented letters to the editor by such well-meaning people as D. Düsterhirn (Dr. Foghead) and Carl Immerkrank (Carl Eversick), a fiction characteristic of the "moral weeklies". But while the manner was informal and popular, the medicine was derived from current academic discussion, the theories and opinions at Halle, and the circle of doctors at Nuremberg, who also published the Commercium litterarium, ${ }^{27}$ a specialized Latin medical journal, one of whose editors was Goetz.

The Patriotische Medicus contained a number of case histories. These compare well with the case studies of Stahl in which age, constitution, and general character (attention to the dominant habits) of the patient are given first, followed by a description of the disease, in which particular attention was paid to the developmental aspect: the time at which the symptoms appeared, their severity, the complications, the relapses, the paroxysm of the fever, etc. The following example is a standard one of its kind; in the issue of Monday, 4 June 1725 (No. 28) Conrad Kinderlieb wrote of his daughter:

a ten year old child, slim, of healthy constitution, and with a quiet and composed character. Four weeks ago she felt such a tiredness combined with temperature [Hitze] that she went to bed. A day later she developed spots but with no feeling of pain. One could recognize that it was "Blattern" or the "KinderPocken" [smallpox]. On the fourth day, however, she became very restless. On the night of the 9th to the 10th day she spent a very disturbed night, and the restlessness continued for another day and night. She was then somewhat better and developed some appetite. On the 10th day she felt an inner frost which recurred at irregular intervals thereafter. But one did not really pay much attention to this because now she experienced such great heat that her brain was affected. [weil inzwischen die Hitze so starck gewesen dass auch der Kopf davon eingenommen] She became confused [verwirrt]. In these ten days she suffered from constipation, somewhat relieved by medication. But the perceptible improvement this occasioned did not last. For several hours each day the girl fell into severe delirium [Raserey] after which she remained exhausted [Mattigkeit] and filled with fear until, at last, she fell asleep. On the 13th day, when the pustules were at their height, the patient became very active and showed signs of apprehension [Bangigkeit]. She complained most frequently, however, about unbearable anxiety of the heart [unleidliche Herzens-Angst], (angor animi). She was also seriously plagued by gas. The outbreak of pustules was at its height at this time. In the succeeding nine days she slept, but with fits of delirium, much heat and unrestfulness. Then a mild appetite and peace returned for one night. Next morning she experienced "inner frost", then again 12 hours of peace. The inner frost continued and she spent a disturbed night. During this time her mind did not suffer, but the following day she raved until noon. The doctors had entertained some hope until then, had given her the red heart powder and liquids to strengthen the heart [rothes Herz-Pulver und Herz-stärckende Wasser]. Now they said she had little chance of recovery.

The letter ended with a plea for a speedy reply. The letter, of course, was fictitious. This should not, however, lead to a false evaluation. The descriptive pattern is a perfect example of how observational cases were recorded. It focuses on a minute retelling of the progression of an illness. It lays stress on time, progression, complications, the perceptions of the patient, and within this framework, the diagnostic signs of smallpox (days of crisis, fever, pustules). Furthermore the letter is a model for a specific type of medical diagnosis. The fiction supposes and predicates a closely

${ }^{27}$ Commercium litterarium ad rei medicae et scientiae naturalis incrementum institutum, Nuremberg, $1731-1745$. 


\section{Johanna Geyer-Kordesch}

observed case. It emphasizes the individual peculiarity of the development of a fever rather than the rubric of its diagnostic indications.

The observational description of cases had a specific place in the medical scheme of things among the followers of Stahl. It was not, as in other uses of case notebooks, a record of the patient and his treatment to be referred to and filed away. Its purpose was not that of a record so much as a learning instrument. "Observations" meant, according to Overkamp, writing out details in such a way "that even those who know almost nothing would then comprehend as much as if he himself had experienced it and had treated the patient."2s Overkamp, however, tended to concentrate on the details of surgery and on frequent borrowings from other doctors' descriptions. Stahl disliked compendiums intensely, and in the collegium casuale or the observationes clinico-practicae used only his own experience. The observational case in the Praxis Stahliana thus had a specific didactic purpose.

As can be seen in the Kinderlieb letter, the purpose was to get away from a set of "symptoms" which led all too quickly to the application of traditional remedies (bleeding, purging, and sweating), instead of those which took the developmental stages of the illness into account. We can discern the double preoccupation with the timing and rhythm of the fever and with the appropriateness of intervention at the proper interval with medication. The mild purgative on the tenth day, the medicative support for the heart - whatever its effectiveness - the awareness of the outbreak and full development of fever delirium on the part of the physicians, all indicate that proper timing, effective intervention, and above all awareness of pattern were paramount. All the case presentations in the Patriotische Medicus communicate the idea that the rhythm and development of an illness produce and vary the symptoms, rather than the idea that a catalogue of symptoms should immediately lead to medication.

The observational case was the practical extension of Stahl's theory. In this the Stahlian approach to medicine was unique in the eighteenth century. The theory provided the rationale for curing, and the case was its practical test. Because Stahl maintained that the timing of remedies rther than the factor of their composition was essential for healing, he ran counter to the simple conception of a set of drugs matching a set of symptoms. He would not, for example, have accepted the flat statement that cinchona bark cures fevers, or aspirin headache. He would have insisted that only a certain application of cinchona in a very particular pattern of febrile illness would lead to health.

The interest in cases derives from a differently defined relationship between physiology and pathology. As we have seen from Bontekoe and all those he criticized, the "state of disease" can be traced back to specific material disorders, malfunction expressed in quantifiable physical terms. These are all "internal" to the extent that the specific disease almost vanishes as an "entity" to be absorbed in the relationship of "thick" or "slow" blood to the heart (pulse rate), tissues (corruption through properties in the blood), or vital functions (imbalance of malignant material). Physiology and pathology in the theoretical system of Stahl were not mechanistic. The

\footnotetext{
28 Overkamp, op. cit., note 9 above, p. 433.
} 


\section{Fevers and other fundamentals: Dutch and German medical explanations}

"state of illness" was not referrable to a single set of material malfunctions, but represented a pattern of circulation, excretion, secretion, and mental influences gone wrong. To pinpoint the specific disease in the individual patient, therefore, means that in each case the interlocking pattern of pathological "mistakes" (Stahl called these the errors of nature) must be determined.

In regard to fever, Stahl held the explanation of his contemporaries to be erroneous. Fever, or indeed illness, was not a phenomenon praeternaturam which was harmful in itself and originated in "discrasis, cacochymiis, and corruption of the blood and fluids" 29 and only caused material or mechanical patterns of reaction. Instead, fever and other illnesses were related to an effort of the whole organism to overcome certain disruptions and harmful intrusions within its own dynamic realm..$^{30}$

In view of this basic redefinition of the behaviour of the organism in disease - Stahl was the first to use organism in this sense - the observational case assumes a prime importance in the work of the physician. It allows him to individualize his observance of disease, and to attain a knowledge of pattern plus symptoms, rather than fixing on a mechanical or chemical explanation with symptoms (such as preternatural heat) of only the most general nature. One recalls that in Bontekoe's criticism of his contemporaries he specifically attacked their lack of attention to the composite picture of all fever symptoms. But Bontekoe in his own formulation of an "internal" theory had come back to a monocausal origin of illness in the "types" of pathological composition of the blood and fluids. Bontekoe did not use observational cases as a source of knowledge. Instead, he relied on anatomical and mechanical knowledge. Observation was mainly restricted to the effects of cures and drugs. Stahl on the other hand tried to use the dialectic between a general theory of organism and dynamics within the body and the observation of clinical (bedside) case histories to the advantage of better practical treatment of patients. He once wrote that Germany harboured a great many ill people because German physicians had closed their eyes to the Historia morborum clinica and simply prescribed opium. ${ }^{31}$

In Stahl's method there was a clear relationship between the theory and the case history. He felt the grasp of the processes within the body would aid in understanding the particular - but specifically different - processes of illness. Because he did not construct his theory on the more restricted foundation of a very limited set of cause and effect relationships, such as those of explaining fever through pulse rate changes, through circulatory friction, or fermentation, he was able to formulate general principles while separating the phenomena of the particular case. The general principles were applicable to the methodus medendi, but the actual therapeutic means had to be judged according to the case at hand. This can be well illustrated in terms of the fevers.

In the Theoria medica vera in Section IV of the Pathologia he discussed fever "in

${ }^{29}$ Observationes clinico-practicae, 1718, preface, p. [vi.]

${ }^{30} \mathrm{Ibid}$., p. [vii.] The term "organism" in Stahl's medical theory needs a detailed and full exposition. It is central to his thinking and influence in medicine. However, it does not derive solely from medical considerations, having deeper roots in other contemporary debates on religious (concept of the soul) and philosophical (materialist definitions of the body) questions. I hope to clarify its meaning in the monograph on Stahl.

${ }^{31}$ Stahl, Untersuchung der übel-curirten und verderbten Kranckheiten, Leipzig, 1726, p. 45. 


\section{Johanna Geyer-Kordesch}

genere". As intended, this was a synoptic view. It drew together all the general characteristics of fever as they may manifest themselves. Fever was, as he wrote,

a perceptible and uniform change in the movement of the blood, pervadingly accompanied by differentiated feelings of heat, cold and a low physical condition not conducive to the free exercise of the voluntary motions.... Ordinarily these characteristic symptoms are accompanied by recognizable disturbances in the appetite, digestion, and internal processes of nutrition, in the excretion of unnecessary substances, in the retention of matter useful for the body and its final assimilation, that is, in the whole phenomenon of nutrition. In addition, marked and perceptible disturbances occur in the excretions of the first as well as the second system of digestion: which is to say in the transpiration and expulsion of the urine. Simultaneously a state of torpor develops in the animal functions, while the general level of sensitivity is raised to a hyperactive state and acquires an unusual intensity, both in respect to ordinary sensations as well as in particular respect to a peaceful sleep.

Stahl here described fever in symptomatic terms (feelings of heat, cold, low physical condition, disturbances in appetite, digestion and sleep). What he described as symptoms were to others, as in the Traité, events in a physiological mechanics. Stahl did not trace fever to a specific physiological event. He delineated only the repercussions within the other vital processes, those of nutrition, expulsion (excretion), and transpiration (secretion). Fever, taken physiologically, then became a particular type of movement traceable in the vital reactions of the bodily functions. He could then extend the perception of vital patterns in the perceptual and mental realm, as he did in Section IV, and included such effects of fever as heightened sensibility, effect on sensory information, and on the mental state of the patient. Contrary to the strictly physiological cause and effect explanation of the materialist medical science advocated in Holland (Bontekoe was here not so different from Boerhaave), the approach of Stahl allows for a very flexible phenomenological description of fever. Not, so to speak, materially defined, but defined as a pathological movement to which can be ascribed symptomatic reactions. The advantages for curing and medication of this approach are obvious: its logic is not one of purging or bleeding away the "cause" of preternatural heat, or malignant substances caused by putrefaction or fermentation, but one of remedial attention to the disruption of vital processes.

Stahl integrated fever into his concept of vital processes. Although he connected it with the range of pathological symptoms described above, he did not necessarily conceive of it as a malignant force. Since he separated it from a direct material cause, he could maintain that it could be in essence a very beneficial "motion". It served, as Storch quoted him as saying in an epistola familiaris of 1719 republished in the Praxis Stahliana of $1728 .^{32}$ to increase the activity of the vital processes of excretion and secretion and thereby to aid nature to re-establish the balance of health. The role of the physician was to moderate beneficially these "motions" (applicable here to excessive pathological symptoms) and to support those processes initiated with fever which help reduce the disease. This remedial attention to the activity within the vital processes as a logical product of the Stahlian explanation of fever resulted in very specific therapeutic guidelines. First, it reduced the amount of medication, and the use of diverse and frequently applied medication, and placed value on supportive or strengthening medication. Second, it introduced a shift in emphasis: although the

${ }^{32}$ Praxis Stahliana, op. cit., note 21 above, pp. $165 \mathrm{ff}$. 


\section{Fevers and other fundamentals: Dutch and German medical explanations}

materia medica was still important, even more essential was its judicious application. Once more, Stahl had introduced a significant change. While contemporary practice placed its faith in the composition of the drug, counteracting the material nature of disease with the material composition of the drug (the extreme examples are the vomitoria), the Stahlian method required knowledge of the developmental pattern of the illness to effect the cure with the help of medication. Hence, once again, the need for the Historiam morborum clinicam. When Stahl was asked to produce a more detailed account of his medicative practice, he rejoined that he was not holding back his arcana. (He in fact used a very small number of remedies.) And he added very pointedly: "Comprehendite meam Methodum, habebitis mea arcana". ${ }^{33}$

An example in respect to fever well illustrates Stahl's method. He wrote in the same epistola familiaris that if one knew the species and characteristics of the remedies one was using, if they were of a mild nature rather than harsh, and if they were applied at the correct time, they would satisfy the method. This was especially useful for all kinds of fever, in which a few remedies would suffice, if applied at the right moment. As opposed to this, even the best remedies if given in the wrong order would not only remain ineffective, but would also cause harm or confusion. This pertained in particular to alexipharmics, hot diaphoretics, excessive warmth, and forced sweating. Even more harm would be caused if these remedies, designed to excite ("internal" motion) and increase heat, were applied when the paroxysm had reached its height. One could be sure that at the beginning of febrile heat no useful sweating takes place. This was different during the time that the febrile heat had begun to diminish, and the paroxysm had become milder. If sweating was to be beneficial at all, however, it should not be driven to excess and not culminate in the shedding of a great deal of water, but rather used to sustain a moist vapour. And where one advised the patient to await sweating, this should be done because one wanted to avoid his risking exposure to cold, rather than as an attempt to expel more fluid. ${ }^{34}$

The methodus medendi of Stahl, as the example above shows, demanded a very experienced doctor, with enough confidence to defy what Bontekoe spoke of as the advice of empirics, the counsel of friends of the patient, and domestic remedies. Anyone who knows the general cures applied to fevers in this period will recognize that sweating in heated rooms was a favourite one, doctor or no doctor. Patients also tended to expect a physician to supply a great number of remedies - one only has to recall the statement in the Patriotische Medicus that a doctor's office was not to be equated with prescribing a succession of drugs. Johann Storch in the Praxis Stahliana gave a simple and practical answer to the patient's demand for medication: in intermittent fevers, after one has decided on the treatment and the patient still wants a remedy every hour, one should turn to the expedient of prescribing every 2 or 3 hours a simple and harmless liquid. ${ }^{35}$

To cover the full range of therapeutic and medicative advice in respect to the fevers in the Praxis Stahliana would require a lengthy book. I have used some examples here

\footnotetext{
33 Ibid., p. 165.

34 Ibid., pp. 166-167.

$3 s$ Ibid., p. 159.
} 


\section{Johanna Geyer-Kordesch}

only to try and point out that among the more critical physicians of the period the medical question posed by the encounter with feverish illnesses was not identification but how to cure. The names were already there, retained in the corpus of traditional medical knowledge. Nowhere in the literature used here was identification a problem when the symptoms were fairly clear. However, severe problems emerged in the selection and use of drugs, and through complications in the fever itself, either through "false" medication or through external causes. These are the problems we will consider more closely.

Sometimes it seems easier for medical science to be faced with the identification of an epidemic of smallpox or plague than with something like catarrhal fever. Illnesses in the late seventeenth and early eighteenth centuries - as the case histories suggest were both lengthy and tended toward complication: either from external causes, illjudged actions on the part of the patient, or the "false" practices to which Bontek oe or Stahl were so opposed. In the Patriotische Medicus, where three particular fevers were discussed, Blattern (smallpox), Fluss-Fieber (fever with discharge, catarrhal fever), and the langwieriges Fieber (continuous fever), most space was allotted to the complications and variations possible after contracting the "fever" ${ }^{36}$ In smallpox, the description took in various sub-categories of the disease, and gave a detailed account of what to look for in the length and severity of the fever. Catarrhal fever was a category of greater ambivalence than the more clearly delineated forms of smallpox. Its complications were regarded as much more numerous and contingent than those of the more predictable diseases such as smallpox. As stated in the Patriotische Medicus: "a good-natured catarrhal fever can develop into a lingering and hectic one, if the sick person is exposed to cold or if powders not congenial to the stomach and cooling remedies are heaped upon him." ("aus gut-artigen Fluß-Fieber kann ein schleichendes und hektisches werden, wenn der Kranke sich erkältet oder mit Magenbeschwerenden Pulvern und kühlenden Medicamenten Überschüttet wird"). ${ }^{37}$ The change in the nature of fever, from "good-natured" to a chronic or "lingering" state was not perceived as unusual. In fact, a variety of places and conditions of such possible Umschlag, (turns), in the nature of the fever was described. These changes were not a part of the normal course of the disease, but were complications either externally caused by unfavourable conditions or false medication. They were not part of the normal prognostic pattern of the fever. The catarrhal fever shows just how central the problem of complication and variation of a fever was for this period.

Even more than the catarrhal fever, the fevers described as continua or ephemera emphasize that medical explanation did not primarily seek a precise knowledge of illness through a specific system of identification. The label, in this period, was no more than a diagnostic shorthand. What mattered was the description given with the label, because here, in the recognition of "normal" and "complicated" variation, the fever became medically manageable. To learn the descriptive range, as the "observational" cases give it, meant that those involved in healing could guess at the rhythm and timing of illness, therapeutically modifying the dangerous habits of

\footnotetext{
${ }^{36}$ See the Patriotische Medicus for 4 June 1725; 18 June 1725; 9 September 1726.
}

37 Ibid., 9 September 1726. 


\section{Fevers and other fundamentals: Dutch and German medical explanations}

disease while supporting those "actions" of the body which seemed beneficial. This observational pattern of fever description, open as it was toward complication and variation, actually denied much of the value of scientific specificity, or disease entities.

The same held true for such a large number of diseases that the publisher Eyssel in Leipzig decided to publish a German translation of all the relevant Latin treatises of Stahl on the subject. This was the Untersuchung der übel curirten und verderbten Kranckheiten (Examination of ill-cured and corrupted diseases) of 1726 . This long book (over 600 pages) covered a wide range of malpractice, including surgical errors, "false" medication, physicians' misjudgments, and what Stahl called the potential errors of nature. The word verderbt was a translation of the Latin corruptio, Stahl wrote, and when applied to disease meant that type of illness which was treated against its own nature (pattern), and was "turned" and worsened through external circumstances or through lack of judgment on the part of the doctor. ${ }^{38} \mathrm{He}$ went on to point out that the modern physicians, in claiming superior knowledge in medicine, had disparaged the categories and descriptions of the ancients, and yet for all their innovation had neglected this one area of decisive importance. It really would not matter, he wrote, characteristically dismissing the pride of the moderns in their scientific acumen, if it were not for the fact that every single day (tag-täglich) one encountered ill-cured and corrupted diseases in practice. Since they were not acknowledged, they effectively resulted in a wrong diagnosis and the wrong prescription of remedies. The symptoms were not indicative of the actual cause of the pathological disorder. They were also distorted, usually made more severe, and if the physician then treated for a severe case of illness instead of recognizing the true source of disruption, he could produce a chronic ailment instead of a cure. ${ }^{39}$

Stahl's particular attention here was focused on the alteration caused in illness by the remedies administered by physicians. The discussion was long and detailed, covering many types of ailment. We will draw on only those examples applicable to fever. Laxatives in febrile illnesses with rashes were harmful because they taxed the constitution and caused disorderly "motions".40 In cases of puerperal fever they were dangerous. Their use in these and other illnesses he mentioned would usually result in death. Vomitoria would usually cause fear, constricting of the breast, stomach pains, continued or ill-timed vomiting, empty choking, and would inhibit the necessary processes of natural evacuation. Women would spit blood, those with tuberculosis might be fatally harmed. ${ }^{41}$ The two most fashionable remedies of the day, Stahl wrote, opium and Cortex chinae (cinchona bark), were very frequently misused. ${ }^{42}$ Doctors did not use them to correct internal "motions" which had become disorderly, but misused them completely. Stahl mentioned cases of death because of the use of impure opium. It also produced apoplexy, paralysis, stupor (Schlafsucht) or a continuous and incurable dizziness (Schwindel). The disease itself would develop entirely strange symptoms. When encountering such symptoms it was best to pay close atten-

\footnotetext{
33 Stahl, op. cit., note 31 above, p. 7 .

39 Ibid., pp. 4-9.

${ }^{40}$ Ibid., p. 41.

41 Ibid., pp. 42-43.

42 Ibid., pp. $144 \mathrm{ff}$.
} 


\section{Johanna Geyer-Kordesch}

tion to what the patient had received as medication, instead of puzzling after the nature of the illness, and if one discovered the use of opium, as no doubt one would, one should not wonder at the state of the patient. ${ }^{43}$

In respect to cinchona, it was not to be recommended in tertian fever, because it resulted in either immediate or future harmful symptoms or inconvenience for the patient. It was as harmful as other astringent medication which tended to block up the body. The practice of medicating against severe sweats in febribus continuis compositis could change the nature of the illness. If one did not use the right medicine, or the patient exposed himself to cold, or sweating was prevented altogether through drugs, then the fever would become a "slow" fever, or it would return with great force, or would become a consumptive fever. One should not fear sweating, but should seek on the other hand to strengthen the body, and when health was restored the sweating would disappear by itself. ${ }^{45}$ In general, fevers should not be looked upon as diseases in themselves, because some fundamental errors resulted from such a definition. For example, it was an error to regard the evacuations which occurred in fevers as the sickness itself. (Stahl here referred to theories which defined disease in terms of the imbalance of malignant material, as in the fermentation or putrefaction explanations.) Instead, one should pay more attention that these offices of nature take their correct and periodic course..$^{46}$ In regard to the fevers, doctors would recognize the function of natural excretion and secretion, but at the same time they would refuse to comprehend the order and inter-relationship of these processes. Then they would apply medication at the wrong time, paying no heed to crisis or paroxysm (when the symptoms indicated that the illness was at its height) and caused harm with their means of medication. ${ }^{47}$ This was especially true in such cases as "cold" fevers, when the doctor perceived that vomiting had brought relief to the patient and therefore gave vomitoria in all "cold" fevers. ${ }^{48}$ Or in the case of pestilential fevers, where sweating seemed to have done some good, doctors would then prescribe sweating in all fevers, and what is worse cum regimine, that is, also requiring the patient to cover himself with innumerable blankets, heating the room to a high temperature, and forbidding the patient even to poke one finger from beneath the blankets. ${ }^{49}$ The most irresponsible error, however, was to drive the fever away entirely without sufficient cause. "I do not know", Stahl wrote, "if one should really trust physicians in this and other matters, who do not flinch when they pretend that in each and every case of having driven off the fever they have been utterly successful and the patient has come to no harm. Especially when one hears from persons both mannered and poor (vornehmen, mittleren, und geringen Personen) facts quite to the contrary."\$o

The discussion in this extraordinary book on malpractice goes on. It shows a very careful physician at work, whose scepticism and unprejudiced eye have driven him to

43 Ibid., p. 146.

4 Ibid., p. 147.

45 Ibid., p. 236.

46 Ibid., p. 244.

47 Ibid., p. 245.

48 Ibid., p. 245.

49 Ibid., p. 246.

so Ibid., p. 246. 


\section{Fevers and other fundamentals: Dutch and German medical explanations}

state some unpleasant truths to those engaged in the same profession. Perhaps this is why Albrecht von Haller, who spent most of his time in the realm of scientific experiment, compiling compendiums of medical knowledge, but not practising much, called Stahl a "homo acris et metaphysicus". Stahl's only recourse in the face of those practices he knew his contemporaries to be using was to repeat tirelessly his advice to pay attention to the complication and pattern of disease and to understand it rather than to subvert it with too many remedies. It does not seem unfair or unrealistic when Stahl insisted that nature often has a better way of overcoming disease with the doctor as her servant rather than as her master. He certainly earned the synonym used in the many vernacular German medical books published by his students from his teaching manuscripts in Halle when they wrote in the title "according to the Stahlian or natural method of curing".

\section{SUMMARY}

We have come to the subject of fevers in a very roundabout way, hoping to extend the field of inquiry on illness and medicine at the close of the seventeenth century and the beginning of the eighteenth century to the more pressing and controversial matters. Those issues go beyond the narrow question of the classification of fevers or which symptoms identify a particular fever. We have seen that in Holland and in Germany, quite a lively controversy surrounded the fevers, but that it did not have well-defined limits. It encompassed the themes of "ancients" versus "moderns", enlightened medicine, drugs, purging, "false" medication, and the concept of illness itself. In other words, the theme of "fevers" merged with the cares and woes of medical practice.

The evidence was taken from a particular group of medical publications which was certainly innovatory: books by Dutch and German physicians, who did not agree with the medical explanations or practice of their contemporaries. In general, one can say it represented the entry of specifically medically oriented themes into the upsurge of the more popularly minded literature of the eighteenth century. This is particularly true of treatises like the Traité des fievres and the periodical Der Patriotische Medicus, whose object was to bring medical discussions before a much wider audience than that of medical faculties and their students.

In regard to the fevers, this material showed that febrile illnesses were still defined in relation to their physiological origins and not according to their own "ontology". The body produced the disease rather than the laws of the disease being imposed on the body. Classification was not at issue. It would not have solved anything. Identification and description of fevers, in the case of the followers of Stahl, however, received a new impetus. This was related more to concern with therapy than to scientific investigation. Stahl's theory of the organism and the attendant revision of the concept of illness called for a detailed knowledge of periodicity in the disease and concomitant knowledge of medicative doses and timing. The "observational case" became integral to proper therapeutics.

In other contemporary views fevers were explained in chemiatric or mechanistic terms which logically supported the physiological expedience of ridding the body of harmful material produced within it. Purging, bleeding, and sweating were perfectly 


\section{Johanna Geyer-Kordesch}

explicable in theoretical terms. Bontekoe was the most forceful in destroying this very logic. However, his own theory remained "internal". In practice, he advocated chemical drugs.

The most pressing practical problem in medicine among learned doctors was not seen as scientific investigation into disease entities. Malpractice and the complication of the fevers themselves proved far more immediate. The detailed and often correct dismissal of curing and medicative practices on the part of Bontekoe and Stahl illustrates a very positive side of eighteenth-century medicine. It was hardly as monolithic or backward as those who point with glee at Molière's satire of the latinizing and purging doctor would have it. 